\title{
THE FACTORS ASSOCIATED WITH ANXIETY AND DEPRESSION IN SLOVENIAN ARMED FORCES MEMBERS ON A PEACEKEEPING MISSION IN THE WESTERN BALKANS DEJAVNIKI, POVEZANI Z DEPRESIJO IN TESNOBNOSTJO PRI SLOVENSKIH VOJAKIH NA MIROVNI MISIJI NA ZAHODNEM
}

\author{
BALKANU \\ Polona Selič1, Jasna Dzanic Unger², Katja Pesjak , Janko Kersnik ${ }^{1}$
}

Prispelo: 31. 7. 2012 - Sprejeto: 27. 12. 2012

Original scientific article

UDC 61:796.034-053.2

\begin{abstract}
Objective: To identify the factors associated with the onset of depression and anxiety in professional soldiers on a peacekeeping mission in Kosovo in 2009.

Methods: A cross-sectional study of 244 members of the Slovenian Armed Forces on a peace-keeping mission, using the Depression Self Rating Scale, the Self-Rating Anxiety Scale and a background questionnaire, was performed. Results: A 6.9\% prevalence of depression and a 7.9\% prevalence of anxiety were identified. The presence of a chronic pain condition and the recent termination of an intimate relationship were independently associated with the onset of either anxiety or depression or with a co-morbidity of anxiety and depression.

Conclusions: In spite of medical and psychological examinations prior to peacekeeping operations, the onset of anxiety and depression calls for special attention and empowerment by teaching peacekeepers how to use their social support and personal mastery resources.
\end{abstract}

Key words: depression, anxiety, pain, military personnel, operations other than war

Izvirni znanstveni članek

UDK 61:796.034-053.2

\section{Izvleček}

Namen: Določiti dejavnike, povezane z nastopom depresije in tesnobe pri poklicnih vojakih na mirovni misiji na Kosovu.

Metode: Presečna študija, v katero je bilo vključenih 244 pripadnikov Slovenske vojske na mirovni misiji, je bila izvedena leta 2009. Uporabljeni so bili Zungov vprašalnik za samooceno depresije in anksioznosti, lestvica za samooceno kronične bolečine ter vprašanja o demografskih značilnostih.

Rezultati: Pojavnost depresije je bila 6,9\%, anksioznosti pa 7,9 \%. Prisotnost kronične bolečine in nedavna prekinitev intimnega razmerja sta bili neodvisno povezani s pojavom anksioznosti ali depresije oziroma s sopojavljanjem obeh.

Zaključek: Glede na to, da so bili pred odhodom na mirovno misijo vojaki celovito zdravstveno pregledani in psihološko ocenjeni, terja pojav anksioznosti in/ali depresije na mirovni misiji posebno pozornost. Predlagamo poučevanje mirovnikov o uporabi in krepitvi socialne podpore ter osebnih virov odpornosti.

Ključne besede: depresija, tesnobnost, bolečina, vojaki, mirovne operacije 


\section{INTRODUCTION}

The prevalence of mental disorders in various countries ranges from $4.7 \%$ in Nigeria up to $26.4 \%$ in the USA (1). In primary care settings, the reported prevalence from studies that provided data from both a standardised interview and self-rating is between $6 \%$ and $17 \%$ (2). The World Health Organisation's study of mental disorders in general health care screened over 25,000 people in 14 countries worldwide and assessed 5,500 in detail. A quarter had well-defined disorders, and a further $9 \%$ had sub-threshold conditions. The most common disorders were depression (10\%), generalised anxiety disorder (8\%) and harmful use of alcohol (3\%) (3). Major depressive disorder (MDD) is a common condition, widely distributed in the population, and usually associated with moderate to severe symptoms and role impairment. The prevalence of MDD over a lifetime in the USA was $16.2 \%$, while for 12 months it was $6.6 \%$, the 12 month cases being categorised as $10.4 \%$ mild, $38.6 \%$ moderate, $38.0 \%$ severe and $12.9 \%$ very severe (4). The first large pan-European survey of depression in the community, DEPRESS, showed a 6 month prevalence of $17 \%$ (5). Major depression accounted for $6.9 \%$ of the cases and minor depression for $1.8 \%$. Depressed subjects in both these categories perceived that their working or social lives were substantially impaired by their depressive symptoms. The remaining $8.3 \%$ of depressed subjects considered that their functional impairment was not substantial. A significant proportion of sufferers from depression (43\%) failed to seek treatment for their depressive symptoms (5).

Apart from genetic predisposition and stressful life events, the known risk factors for depression are female gender, age 20-40 years, separated or single marital status in middle aged females, lower socioeconomic status (unemployment rate, lower education, poverty) and the presence of chronic pain and chronic illness $(6,7)$.The risk factors for the persistence of depression identified in the review presented by Gilchrist and Gunn (7) were how severe and chronic the depressive episode was, the presence of suicidal thoughts, antidepressant use, poorer self-reported quality of life, lower self-reported social support, experience of key life events at the time, lower education level and unemployment. Clinically significant depressive symptoms are highly prevalent in primary care patients; however, depression is an infrequent patient complaint. Therefore, depression often goes unrecognised; only half of the patients with depression are identified and even fewer are treated $(8,9)$.
The literature reviewed by Kessler et al. is consistent in showing that generalised anxiety disorder (GAD) is a common mental disorder that typically has an early age of onset, a chronic course and a high degree of co-morbidity with other anxiety and mood disorders. However, the clinical course of GAD is less consistently associated with other diseases than that of other anxiety and mood disorders. There is a strong co-morbidity between GAD and major depression; most people with this type of co-morbidity report that the onset of GAD occurred before the onset of depression (10). Compared to depressed patients without GAD, patients with both depression and modified generalised anxiety disorder have higher levels of suicidal thoughts, poorer social functioning, a greater frequency of other anxiety disorders, eating disorders and somatoform disorders, a greater level of pathological worry and a higher risk for generalised anxiety disorder in first-degree family members (11).

Overall, the prevalence of pain is greater among females and among older people. Although most people reporting chronic pain do not meet the criteria of a depressive or anxiety disorder, depression/ anxiety spectrum disorders are often associated with experience of some degree of chronic pain. Studies show that the age-standardised prevalence of chronic pain conditions for the previous 12 months was $37.3 \%$ in developed countries and $41.1 \%$ in developing countries, with back pain and headache being somewhat more common in developing than developed countries (12). Over $75 \%$ of depressed patients in primary care complain of painful physical symptoms such as headache, stomach pain and neck and back pain as well as non-specific generalised pain. The presence of such symptoms predicts a greater severity and a less favourable outcome of depression, together with a poorer health-related quality of life. World Health Organisation data obtained in primary care centres worldwide show that $22 \%$ of all primary care patients suffer from persistent debilitating pain, and that these patients are four times more likely to have co-morbid anxiety or depressive disorder than pain-free primary care patients. Increasingly, major depression is seen as being composed of psychological, somatic and painful physical symptoms (13). Co-morbid depression and chronic pain represent a significant source of disability in the workforce. Other risk factors for absenteeism include a younger age, greater income and higher level of education (14).

The association between psychosocial work-stress variables and major depressive episodes was examined by Blackmore et al. in a population study in Canada 
(15). High job strain was significantly associated with depression among men, and lack of social support at work was significantly associated with depression in both genders. A significant proportion of the workforce experienced major depressive episodes in the year preceding the study. Gender differences appear to affect work stress factors that increase the risk of depression (15). The impact of work on the risk of future psychiatric disorder has been examined in several longitudinal studies. A large epidemiological study of civil servants showed that social support and control at work protect mental health, while high job demands and effort-reward imbalance are risk factors for future psychiatric disorder (16).

Military jobs are known to be especially stressful due to the constant need to deal with critical and acutely stressful situations; however, significant stress has also been recognised in the routine, peacetime military work environment $(17,18)$. The term "operational stress" describes soldiers' stress in the context of operations other than war (OOTW) (19), suggesting that both combat stressors (e.g. witnessing death of others, taking hostages) as well as contextual stressors (e.g. increased levels of marital, family and financial stress) play an important role in the development of 'peacekeeping stress'. In addition to the exposure to potential danger, peacekeeping stress in some cases is potentially even more frustrating than combat stress (20). In the last decades, Western armies have been involved in operations other than war (OOTW), such as humanitarian aid, peacekeeping operations and peaceenforcing operations. Since 2004, when Slovenia joined the North Atlantic Territorial Organisation (NATO), the Slovenian Armed Forces have taken an active part in supporting international peace. The tasks of Slovenian troops in Kosovo include the maintenance of a secure and stable environment, ensuring favourable conditions for the transfer of political power to civilian authorities, communication and checkpoint control and the protection of highly important facilities (21).

Since there is a lack of appropriate research data on the prevalence of depression and anxiety in those participating in OOTW operations in Slovenia, this study is to be considered as a beneficial contribution to the field.

\section{METHODS}

The study design addressed the question: Which factors are associated with the onset of depression and anxiety in the participants in an OOTW peacekeeping mission?

\subsection{Participants}

Of 244 members of the Slovenian Armed Forces on the peacekeeping mission KFOR in Kosovo, located at the military base Villagio Italia (Italian village) near the town of Peć, in February 2010, after five months of service in OOTW, 203 soldiers ( $83.2 \%$ response rate) willingly participated in the data collection. The questionnaires were administered with the help of military nurses. Confidentiality was ensured by the anonymous administration of questionnaires, which were coded and delivered to the home country by military personnel and which are now archived in the Department of Family Medicine at the Faculty of Medicine in the University of Ljubljana.

All the peacekeepers underwent a thorough medical examination and mental health exploration prior to their departure for Kosovo. At the beginning of the OOTW, all participants were assessed and considered to be completely healthy.

The National Ethics Committee approved the protocol of the study on 7 June 2009; reference number 41/04/09.

\subsection{Instruments and measures}

The instruments relevant to this study are the background questionnaire, the Depression Self Rating Scale (SDS), the Self-Rating Anxiety Scale (SAS) and the Visual Analog Scale for self-assessment of the intensity of pain. All were administered in a Slovenian language translated version. The reliability of the SDS and SAS was tested by Cronbach's alpha coefficients. Based on this, all the instruments reached the recommended threshold of 0.7 (22); the Cronbach alpha for SAS was 0.877 and for SDS was 0.878 .

To assess anxiety and depression Zung's Depression Self-Rating Scale (SDS) (23) and the Self-Rating Anxiety Scale (SAS) (24) were administered. They are widely used, comprehensible and easy to administer. Each of the questionnaires contains a set of 20 assertions. The respondents assess each statement on the Likert scale. Some statements are given in a positive form and others in a negative form; the responses are evaluated from 1 to 4 . The sum for each of the questionnaires is divided by 80 and multiplied by 100 with the total score varying from 25 to 100 points. Depression is determined by the number of points; i.e. up to 49 points there is no depression, 50-59 points indicates mild depression, 60-69 points moderate, and 70 or more points severe depression (23).

The level of anxiety is evaluated similarly, with the criteria for anxiety being mild between 50 and 59 points, moderate between 60 and 69 points and severe for 70 or more points (24). 
In addition to questions concerning the frequency of individual symptoms of both disorders, the respondents marked the presence of chronic somatic diseases and chronic pain, which was later defined as having continued for more than one year.

The intensity of pain was rated on a visual analogue scale (VAS) from 0 to 10: (no pain (0), mild (1-3), medium intensity (4-6), strong (7-9) and unbearable (10)).

The background questionnaire consisted of information about gender, age, marital status and educational level.

\subsection{Statistical analysis}

Appropriate tests were performed on the data, depending on the nature of the variables. In the univariate analysis the Student t-test (for normally distributed variables), the Mann-Whitney test (for abnormally distributed variables), and the chi-square $(\chi 2)$ test (to identify qualitative differences between the groups) were applied. Linear regression modelling was used to identify variables associated with the onset of either depression or anxiety or both. The results were presented by the Beta coefficient, $t$ value and $P$ value. The SPSS 15 software was used for statistical analysis (SPSS Inc., Chicago, IL). A P value of $<0.05$ was considered statistically significant.

\section{RESULTS}

Of 203 participants, 184 (91.6\%) were men and 19 women (9.4\%); this is a greater proportion of male soldiers than in the total Slovenian Armed Forces population $(86.2 \%$ men) at the time of data collection (25).

There was no statistically significant difference in age between men $(29.4 \pm 6.8)$ and women $(29.7 \pm 7.2)$ in the surveyed group ( $p=0.833$ ); the average age was $29.4 \pm 6.9$ years. However, there was a significant difference between male and female participants $(p=0.028)$, more female soldiers being single.

Regarding rank, there were 123 (60.6\%) Privates, $54(26.6 \%)$ Non-Commissioned Officers (NCOs) and $26(12.8 \%)$ Officers. The proportion of Privates in the sample was larger and that of Officers was smaller, compared to the army population in 2010 (Privates: $60.6 \%$ vs. $47.2 \%$ in the population; NCOs: $26.6 \%$ vs. $30.0 \%$; and Officers: $12.80 \%$ vs. $22.8 \%$ ) (26).

Participants by gender, level of education and marital status are presented in Table 1.

Table 1. Participants by gender, level of education and marital status.

Tabela 1. Predstavitev udeležencev po spolu, stanu in ravni izobrazbe.

\begin{tabular}{|l|l|l|l|l|l|}
\hline & $\begin{array}{l}\text { Male / } \\
\text { moški } \\
(\mathrm{n}=184)\end{array}$ & $\begin{array}{l}\text { Female } \\
\text { / ženske } \\
(\mathrm{n}=19)\end{array}$ & $\mathrm{p}$ & $\begin{array}{l}\text { Total / } \\
\text { skupaj } \\
\mathrm{n}=203\end{array}$ & $\%$ \\
\hline $\begin{array}{l}\text { Level of Education / } \\
\text { raven izobrazbe }\end{array}$ & $62(33.7 \%)$ & $4(21.1 \%)$ & & 6.152 & \\
\hline $\begin{array}{l}\text { Vocational School / poklicna } \\
\text { šola }\end{array}$ & $109(59.2 \%)$ & $11(57.9 \%)$ & & 120 & 59.1 \\
\hline High School / srednja šola & $2(1.1 \%)$ & $1(5.3 \%)$ & & 3 & 1.5 \\
\hline College / višja in visoka šola & $11(6.0 \%)$ & $3(15.8 \%)$ & & 14 & 6.9 \\
\hline $\begin{array}{l}\text { University Degree / univerzitetna } \\
\text { izobrazba }\end{array}$ & $88(47.8 \%)$ & $11(57.9 \%)$ & & 99 & 48.8 \\
\hline Marital Status / stan & $93(50.5 \%)$ & $6(31.6 \%)$ & & 99 & 48.8 \\
\hline Single / samski & $3(1.6 \%)$ & $2(10.5 \%)$ & & 5 & 2.5 \\
\hline $\begin{array}{l}\text { Intimate Relationship / dejavni } \\
\text { partnerski odnos }\end{array}$ & & & & & \\
\hline $\begin{array}{l}\text { Intimate Relationship ended / } \\
\text { zaključeni partnerski odnos }\end{array}$ & & & & \\
\hline
\end{tabular}


At least one chronic disease was reported by 9 (4.4\%) respondents (chronic heart disease, obstructive pulmonary disease, asthma, diabetes, rheumatic disease, migraine). Continuous or recurrent pain in any body part in the past year was reported by $31(15.3 \%)$ of the respondents. Out of $44(21.7 \%)$ participants who reported pain in any body part at the time of data collection, $13(29.6 \%)$ reported mild pain, $16(36.46 \%)$ moderate pain and $7(15.9 \%)$ severe pain. The prevalence of anxiety (SAS) was $7.9 \%$ and of depression (SDS) $6.9 \%$.

The Self-Rated Depression (SDS), Self-Rated Anxiety (SAS) and Pain Intensity Rates (VAS) are presented in Table 2.

Table 2. Participants by age, Self-Rated Depression (SDS), Self-Rated Anxiety (SAS) and Pain Intensity Rates (VAS).

Tabela 2. Samoocena depresivnosti (SDS), tesnobnosti (SAS) in intenzivnosti bolečine (VAS).

\begin{tabular}{|l|l|l|l|l|}
\hline & $\begin{array}{l}\text { Male / moški } \\
(\mathrm{n}=184)\end{array}$ & $\begin{array}{l}\text { Female / ženske } \\
(\mathrm{n}=19)\end{array}$ & $p$ & $\begin{array}{l}\text { Total / skupaj } \\
\mathrm{n}=203\end{array}$ \\
\hline $\begin{array}{l}\text { Age (years) / starost (leta) } \\
\text { [21-55] }\end{array}$ & $29.4 \pm 6.8$ & $29.7 \pm 7.2$ & 0.833 & $29.4 \pm 6.9$ \\
\hline $\begin{array}{l}\text { Self-Rated Depression / samoocena } \\
\text { depresivnosti(SDS) } \\
{[20-71]}\end{array}$ & $31.7 \pm 8.7$ & $34.6 \pm 10.0$ & 0.160 & $31.9 \pm 8.9$ \\
\hline $\begin{array}{l}\text { Self-Rated Anxiety / samoocena } \\
\text { tesnobnosti (SAS) [20-75] }\end{array}$ & $30.1 \pm 8.2$ & $31.2 \pm 9.1$ & 0.587 & $30.2 \pm 8.2$ \\
\hline $\begin{array}{l}\text { VAS rate / samoocena intenzivnosti } \\
\text { bolečine [0-5] }\end{array}$ & $0.4 \pm 0.9$ & $0.2 \pm 0.5$ & 0.359 & $0.3 \pm 0.9$ \\
\hline
\end{tabular}

For SAS, mild anxiety was identified in 10 (4.9\%) and severe anxiety in $6(2.9 \%)$ participants $(7.9 \%$ prevalence). For SDS, mild depression was identified in $12(5.9 \%)$ and severe depression in $2(1.0 \%)$ participants (6.9\% prevalence). There was a significant co-morbidity between mild anxiety and mild depression $(p<0.001)$.

A weak negative correlation was found between education level and signs of anxiety $(r=-0.183, p$ $=0.014)$ and depressive symptoms $(r=-0.204, p=$ 0.006 ); higher educated participants were less likely to be either depressed or self-assessed as anxious. Comparing the level of education and the number of respondents with anxiety or depression, statistically significant associations were no longer present $(p=$ 0.914; $p=0.963$, respectively).

Widowed or separated (Intimate Relationship ended, Table 1) and single subjects were the most likely to be anxious, while the lowest rates were in participants living in intimate partnerships $(p<0.001)$.

Widowed or separated subjects were more depressed than respondents who lived in intimate relationships $(p<0.001)$.

Anxiety was significantly more frequent in subjects with chronic disease than those without $(p<0.001)$, and the same was shown for depression $(p<0.001)$.

The frequency of depression and anxiety rose sharply with the intensity of pain. Subjects with higher VAS rates were more anxious $(p<0.001)$. Intense pain was significantly associated with the occurrence of anxiety and depression.

\subsection{Factors associated with self-rated anxiety (SAS) and self-rated depression (SDS): a linear regression model}

Factors Associated with Self-Rated Anxiety (SAS) and Self-Rated Depression (SDS) are presented in Table 3. 
Table 3. Factors associated with Self-Rated Anxiety (SAS) and Self-Rated Depression (SDS): a linear regression model.

Tabela 3. Dejavniki, povezani s samooceno tesnobnosti (SAS) in depresivnosti (SDS): linearna regresija.

\begin{tabular}{|c|c|c|c|c|c|c|}
\hline \multirow[t]{2}{*}{$\begin{array}{l}\text { Characteristics / } \\
\text { dejavniki }\end{array}$} & \multicolumn{3}{|c|}{$\begin{array}{l}\text { Self-Rated Anxiety / } \\
\text { samoocena tesnobnosti (SAS) } \\
(\mathrm{F}=8.904, \mathrm{df}=7, \mathrm{p}<0.001)\end{array}$} & \multicolumn{3}{|c|}{$\begin{array}{l}\text { Self-Rated Depression / } \\
\text { samoocena depresivnosti } \\
\text { (SDS) } \\
(F=7.930, d f=7, p<0.001)\end{array}$} \\
\hline & Beta & $t$ & $p$ & Beta & $t$ & $p$ \\
\hline $\begin{array}{l}\text { Age (years) / } \\
\text { starost (leta) }\end{array}$ & 0.02 & 0.34 & 0.731 & -0.08 & -1.11 & 0.268 \\
\hline $\begin{array}{l}\text { Female gender / } \\
\text { ženski spol }\end{array}$ & 0.04 & 0.56 & 0.577 & 0.11 & 1.73 & 0.085 \\
\hline $\begin{array}{l}\text { Level of } \\
\text { Education / raven } \\
\text { izobrazbe }\end{array}$ & -0.18 & -2.83 & 0.005 & -0.19 & -2.99 & 0.003 \\
\hline $\begin{array}{l}\text { Intimate } \\
\text { Relationship } \\
\text { active / dejavni } \\
\text { partnerski odnos }\end{array}$ & -0.08 & -1.24 & 0.215 & 0.02 & 0.25 & 0.799 \\
\hline $\begin{array}{l}\text { Intimate } \\
\text { Relationship } \\
\text { ended / zaključeni } \\
\text { partnerski odnos }\end{array}$ & 0.26 & 3.68 & $<0.001$ & 0.24 & 3.35 & 0.001 \\
\hline $\begin{array}{l}\text { Co-occurring } \\
\text { chronic diseases } \\
\text { / sopojavljanje } \\
\text { kroničnih bolezni }\end{array}$ & 0.10 & 1.47 & 0.144 & 0.06 & 0.84 & 0.399 \\
\hline $\begin{array}{l}\text { Self-Rated Pain } \\
\text { / samoocena } \\
\text { intenzivnosti } \\
\text { bolečine (VAS) }\end{array}$ & 0.29 & 4.53 & $<0.001$ & 0.31 & 4.79 & $<0.001$ \\
\hline
\end{tabular}

In linear regression modelling, $24.2 \%$ of the variance was explained by factors associated with the occurrence of mild and severe anxiety, i.e. lower educational level, separation or death of intimate partner (Intimate Relationship ended) and intensity of pain (VAS rate); $22.2 \%$ of the variance in the occurrence of mild and severe depression was explained by intensity of pain
(VAS rate), separation or death of intimate partner (Intimate Relationship ended) and lower educational level.

Factors Associated with Co-occurring Self-Rated Anxiety (SAS) and Self-Rated Depression (SDS): A Linear Regression Model $(F=9.209, \mathrm{df}=7, \mathrm{p}<0.001)$ are presented in Table 4. 
Table 4. Factors associated with co-occurring Self-Rated Anxiety (SAS) and Self-Rated Depression (SDS): a linear regression model. $(F=9.209, d f=7, p<0.001)$.

Tabela 4. Dejavniki, povezani s sočasno samooceno testnobnosti (SAS) in depresivnosti (SDS): linearna regresija $(F=9.209, d f=7, p<0.001)$.

\begin{tabular}{|l|l|l|l|}
\hline Characteristics / dejavniki & Beta & $\mathrm{t}$ & $\mathrm{p}$ \\
\hline Age (years) / starost (leta) & -0.03 & -0.44 & 0.660 \\
\hline Female gender / ženski spol & 0.08 & 1.24 & 0.215 \\
\hline $\begin{array}{l}\text { Level of Education / raven } \\
\text { izobrazbe }\end{array}$ & -0.20 & -3.10 & 0.002 \\
\hline $\begin{array}{l}\text { Intimate Relationship active / } \\
\text { dejavni partnerski odnos }\end{array}$ & -0.03 & -0.49 & 0.624 \\
\hline $\begin{array}{l}\text { Intimate Relationship ended / } \\
\text { zaključeni partnerski odnos }\end{array}$ & 0.27 & 3.73 & $<0.001$ \\
\hline $\begin{array}{l}\text { Co-occurring chronic diseases } \\
\text { / sopojavljanje kroničnih } \\
\text { bolezni }\end{array}$ & 0.08 & 1.21 & 0.227 \\
\hline $\begin{array}{l}\text { Self-Rated Pain / samoocena } \\
\text { intenzivnosti bolečine (VAS) }\end{array}$ & 0.32 & 4.96 & $<0.001$ \\
\hline
\end{tabular}

$\mathrm{R} 2=0.248$

When analysing the factors associated with cooccurrence of depression and anxiety in regression modelling, $24.8 \%$ of the variance was explained by the same three factors identified in the previous analysis, i.e. separation or death of intimate partner (Intimate Partnership ended), intensity of pain (VAS rate) and lower level of education.

\section{DISCUSSION}

The objective of this survey was to assess the prevalence of depression and anxiety in peacekeepers in Kosovo. Comparing the results to epidemiological data and other research, the incidence of depression $(6.9 \%)$ in our findings was somewhat lower than in other similar studies. In Slovenia, Klemenc Ketis et al. (27) reported a prevalence of $15.2 \%$ patients with depression in the adult population aged between 18 and 64 years and at least one chronic disease present in $40.7 \%$ of the patients.

With regard to age, soldiers are most similar to the age demographic of students. In 2009, a sample of 1155 students aged 18-52 years was surveyed for the incidence of depression and anxiety (28). Klemenc-Ketis et al. (28) found the prevalence of anxiety in students to be $5.3 \%$; in our analysis, it was somewhat higher, $7.9 \%$. The prevalence of depression among students was $4.5 \%$, while in soldiers there were more depressive symptoms $(6.9 \%)$, which is understandable given the living and working conditions of peacekeepers. A survey of the active population of primary care patients aged between 18 and 64 years with at least one co-occurring chronic disease in Slovenia, indentifying the prevalence of anxiety and depression in a randomised sample of 500 subjects, showed a $15.2 \%$ prevalence of depression (in soldiers $6.9 \%$ ) and $8.4 \%$ incidence of anxiety (in soldiers $7.9 \%$ ) (29). At least one chronic disease was present in $40.7 \%$ of the general population, which is almost identical to that of the student population, where the proportion was $40.3 \%$ (28). The proportion of chronic diseases in soldiers was only $4.43 \%$, which was probably due to the medical and psychological tests administered prior to their departure for the peacekeeping operation. The lower incidence of depression and anxiety in soldiers is partly due to age (i.e. the maximum age of the soldiers in the sample was 55 years), since Copeland et al. (30) reported associations between age and the incidence of depression and anxiety in the general population. The frequency of depression and anxiety rose sharply with the severity of pain (31). We believe that depression can intensify the feeling of chronic pain, while living with 
chronic pain can contribute to depression - knowing that the symptoms of chronic pain, depression and anxiety often overlap in patients $(32,33)$. The co-occurrence of depression and chronic pain is reported to vary from $30 \%$ to $60 \%$ (34); in our sample, the VAS rate was associated with SDS and SAS scores (Table 3, Table 4). Patients with chronic pain have symptoms of depression or anxiety more frequently than those without, with depression intensifying other symptoms (35).

Several psychological factors have been associated with pain perception, but what predisposes certain individuals to be more sensitive to pain remains relatively unknown. Consistent with the bio-psychosocial model, the results of Lee et al. (36) suggest that multiple pain-related psychological measures most likely assess a common underlying factor, which is more predictive of the quality of pain than its intensity (36). Since intensity pain ratings were used in our study, we are therefore reluctant to put much weight on them. Both depression and anxiety are known to be more prevalent in women $(37,38)$, but in our study female gender was not shown to be significantly associated with either the SDS or SAS score (Table 3) or with the co-occurrence of depression and anxiety (Table 4). In one of our previous studies on Slovenian Armed Forces members, longer sick leave duration was found in female soldiers (26) and a negative association between satisfaction with co-workers and female gender was identified (39). It was suggested that special attention should be given to female soldiers when planning supervision, work procedures, and the gender equality policy of the Armed Forces (39). However, in present study, female gender was not identified to be significantly associated with variables of interest, which is probably due to the low proportion of women in the surveyed group.

Level of education was shown to be a factor associated with either SDS or SAS scores (Table 3) or the cooccurrence of depression and anxiety (Table 4), which is in accordance with the results of other authors (16). The death of a significant other can result in a depressive reaction in any individual, regardless of age, who finds such stressors overwhelming. These stressors are most commonly seen, however, in the elderly. The presence of multiple stressors or the inability to cope can result in an episode of depression (40). We showed that the loss of a loved one may generate a bereavement response that portrays a pathological appearance. The end of an intimate relationship due to the death of the spouse or separation was significantly associated with both SDS and SAS scores (Table 3) and the co-occurrence of depression and anxiety (Table 4). The stress of losing a spouse outranks all others, although grieving over the loss of any significant person can, in itself, precipitate depression. Depressive symptoms associated with bereavement are too often overlooked by health care personnel as "normal" for a grieving subject (40).

The psychosocial work environment is also important for mental health. The impact of work stressors on common mental disorders has been reported to differ for women and men (41). Stansfeld and Candy (41) found that job strain, low decision latitude, low social support, high psychological demands, effort-reward imbalance and high job insecurity predicted common mental disorders. A study of Slovenian soldiers showed that anxiety correlates negatively with problem-focused and positively with avoidant coping strategies (42). On the other hand, another study showed that coping strategies do not affect self-reported sick leave in Slovenian soldiers (26).

Since job demands, stress and the coping strategies of the soldiers on missions were not controlled in this study, which is an important limitation, we are not able to speculate about the impact of operational stress on the incidence of anxiety and depression. However, the results from Griffin et al. (43) made us aware of the risks associated with low control at work, since the authors noted that men in the middle grade with low work control were at risk of depression, while those in the lowest grade were at risk of anxiety. Moreover, results obtained in a cross-sectional study by Griffin et al. (44) in British civil servants showed that the demand/control/support model explained the most variance in depression and anxiety symptoms.

Since coping strategies have been shown to moderate the effects of stress on physical and psychological health (45), further research focused on coping in association with depression and anxiety is needed in the Slovenian Armed Forces carrying out OOTW. Emotion-focused coping should be analysed thoroughly, as people who predominantly use emotion-focused coping tend to have poorer psychosocial and physical health outcomes than people who rely mostly on problem-focused coping (46). Most studies of the coping strategies of soldiers indicate that the use of emotion-focused coping is associated with more severe post-traumatic stress disorder (PTSD) symptoms, higher family-related stress, lower psychological well-being and more reported physical illness symptoms (47). In our study, personality traits were not analysed, which is another limitation, since the way people perceive and cope with distress is associated with their personality traits (48).

In peacekeepers, intervention at the level of work design, organisation and management might have 
positive effects on mental health. Furthermore, measures associated with job resources (e.g., social support and skill utilisation) might have a protective effect on depression and anxiety symptoms, as stated by Griffin et al. (44).

\subsection{Limitations}

Aside from coping and personality traits, which were not analysed in the study, it should be noted that our results might not be applicable to military settings in other national armies due to cultural differences. This calls for further research to implement a cross-cultural aspect into studies of anxiety and depression in the military. Further research is needed regarding environmental and situational factors in military settings in order to optimise interventions to reduce anxiety and depression in the military population.

The cross-sectional survey design is inherently limited and, together with reliance on self-reported data, raises questions about the potential for method variance (i.e. same-source measurement bias) to account for our findings. Although the phenomenon being studied could have been assessed only by asking respondents to report an internal state or perception, it would be useful for some other measures to be incorporated in further research design (e.g. thorough checking of medical records to obtain exact health sick leave related data etc.) and measured over time (prospective study), to mitigate the potential effects of method variance.

Due to the structure of the sample in comparison with the whole Armed Forces, the conclusions made are more valid for Privates than NCOs and Officers serving OOTW.

\section{CONCLUSIONS}

Low levels of mental disorders in peacekeeping military personnel support the existing rigorous pre-mission assessment of soldiers sent to OOTW. However, in spite of a lower incidence of depression and anxiety when compared to the general population, a $6.9 \%$ prevalence of depression and $7.9 \%$ prevalence of anxiety have to be taken seriously by Armed Forces health care personnel and commanding officers, especially when taking into account that these conditions appeared after five months of service in OOTW. The results of our study revealed that special attention, psychological support and early identification of emerging symptoms should be provided for subjects reporting chronic pain and those whose intimate relationship has been terminated in the near past. As widows and widowers are easily identified in such a group, identification of intimate relationship problems (e.g. separation) might present a bigger problem. The duration of participation in OOTW should also be reconsidered by Armed Forces health care personnel and commanding officers; however, NATO and other standards to be followed might make a shorter period of service in OOTW impossible.

Future studies should explore how peer support can help in the timely identification of emerging mental disorders. Educational material on the correlates of mental issues might help in identification and selfidentification, thus recognising a need for professional help.

It seems plausible that teaching peacekeepers themselves how to use their social support and individual mastery resources would be beneficial. Another possibility in the military is peer social support intervention, providing members with information and emotional support and resources that are beyond those possessed directly by an individual.

\section{Acknowledgements}

The study was partly supported by the Slovenian Research Agency, Research program code P3-0339.

\section{References}

1. World health organization and world organization of family doctors (WONCA). Integrating mental health into primary care: a global perspective. Available May 30, 2011 from: http://www.who. int/mental_health/policy/Integratingmhintoprimarycare2008_ lastversion.pdf.

2. Zung WW. The role of rating scales in the identification and management of the depressed patient in the primary care setting. J Clin Psychiatry 1990; 51: 72-76.

3. Craig TK, Boardman AP. ABC of mental health: common mental health problems in primary care. BMJ 1997; 314: 1609-1612.

4. Kessler RC, Berglund,P, Demler O, Jin R, Cortez D, Merikangas KR. et al. The epidemiology of major depressive disorder: results from the National Comorbidity Survey Replication (NCS-R). JAMA 2003; 289: 3095-3105.

5. Lépine JP, Gastpar M, Mendlewicz J, Tylee A. Depression in the community: the first pan-European study DEPRES (Depression Research in European Society). Int Clin Psychopharmacol 1997; 12: 19-29.

6. Angst J, Gamma A, Gastpar M, Lépine JP, Mendlewicz J, Tylee A. Gender differences in depression. Eur Arch Psychiatry Clin Neurosci 2002; 252: 201-209.

7. Gilchrist G, Gunn J. Observational studies of depression in primary care: what do we know? BMC Fam Pract 2007; 11: 8-28.

8. Gastpar M, Lépine JP, Mendlewicz J, Tylee A. DEPRESS II (Depression research in European society II): a patient survey of the symptoms, disability and current management of depression in the community, DEPRESS stering committee. Int Clin Psychopharmacol 1999; 14: 139-151.

9. Wittchen HU, Kessler RC, Beesedo K, Krause P, Hofler M, Hoyer J. Generalized anxiety and depression in primary care: prevalence, recognition and management. J Clin Psychiatry 2002; 8: 24-34. 
10. Kessler RC, Keller MB, Wittchen HU. The epidemiology of generalized anxiety disorder. Psychiatr Clin North Am 2001; 24: 19-39.

11. Zimmerman M, Chelminski I. Generalized anxiety disorder in patients with major depression: is DSM-IV's hierarchy correct? Am J Psychiatry 2003; 160: 504-512.

12. Tsang A, Von Korff M, Lee S, Alonso J, Karam E, Angermever MC. et al. Common chronic pain conditions in developed and developing countries: gender and age differences and comorbidity with depression-anxiety disorders. J Pain 2008; 10: 883-891.

13. Lépine JP, Briley M. The epidemiology of pain in depression. Hum Psychopharmacol 2004; 19: 3-7.

14. Munce SE, Stansfeld SA, Blackmore ER, Stewart DE. The role of depression and chronic pain conditions in absenteeism: results from a national epidemiologic survey. J Occup Environ Med 2007; 49: 1206-1211.

15. Blackmore ER, Stansfeld SA, Weller I, Munce S, Zagorski BM, Stewart DE. Major depressive episodes and work stress: results from a national population survey. Am J Public Health 2007; 97: 2088-2093.

16. Stansfeld SA, Fuhrer R, Shipley MJ, Marmot MG. Work characteristics predict psychiatric disorder: prospective results from the Whitehall II Study. Occup Environ Med 1999; 56: 302307.

17. Pflanz SE, Ogle AD. Job stress, depression, work performance and perceptions of supervisors in military personnel. Mil Med 2006; 171: 861-865.

18. Pflanz SE, Sonnek S. Work stress in the military: prevalence, causes and relationship to emotional health. Mil Med 2002; 167: 877-882.

19. United States Army, Combat and operational stress control, United States Army Field Manual 2006 (No. 4-02.51). Available May 30, 2011 from: http://www.fas.org/irp/doddir/army/fm4-02-51.pdf.

20. Lamerson CD, Kelloway EK. Towards a model of peacekeeping stress: traumatic and contextual influences. Can Psychol 1996; 195: 195-204.

21. Slovenian armed forces, international operations and missions. Available May 30, 2011 from: http://www.slovenskavojska.si/en/international-cooperation/ international-operations-and-missions.

22. Bland MJ, Altman DG. Statistics notes: Cronbach's alpha. BMJ 1997; 314: 572

23. Zung WW. A self-rating depression scale. Arch Gen Psychiatry 1965; 12: 63-70.

24. Zung WW. A rating instrument for anxiety disorders. Psychosomatics 1971; 12: 371-379.

25. Selič $P$, Serec M, Petek D, Rus-Makovec M. Basic personality traits and coping strategies in relation to health and burnout among members of Slovenian Armed Forces. Zdrav Var 2010; 49: 61-75.

26. Selič $P$, Petek D, Serec M, Rus-Makovec M. Sick leave and its determinants in professional soldiers of the Slovenian Armed Forces. Croat Med J 2010; 51: 543-551.

27. Klemenc-Ketiš Z, Kersnik J, Tratnik E. The presence of anxiety and depression in the adult population of family practice patients with chronic diseases. Zdrav Var 2009; 48: 170-176.

28. Klemenc-Ketiš Z, Hladnik Ž, Rotar-Pavlič D, Post M, Kersnik J. Self-reported chronic conditions in student population in Slovenia. Zdrav Vestn 2010; 79: 31-41.

29. Klemenc-Ketiš Z, Kersnik J, Novak-Glavač D. Determinants of depression and anxiety in family practice patients with comorbidities. Wien Klin Wochenschr 2010; 122: 35-39.
30. Copeland JR, Beekman AT, Dewey ME, Hooijer C, Jordan A, Lawlor BA. et al. Depression in Europe. geographical distribution among older people. Br J Psychiatry 1999; 174: 312-321.

31. Leo RJ. Chronic pain and comorbid depression. Current Treatment Options Neurol 2005; 7: 403-412.

32. Smith BH, Elliott AM, Chambers WA, Smith WC, Hannaford PC, Penny K. The impact of chronic pain in the community. Fam Pract 1999; 18: 292-299.

33. Gallagher RM, Verma S. Managing pain and comorbid depression: a public health challenge. Semin Clin Neuropsychiatry 1999; 4: 203-220.

34. Lovibond PF, Lovibond SH. The structure of negative emotional states: comparison of the Depression Anxiety Stress Scales (DASS) with the Beck Depression and Anxiety Inventories. Behav Res Ther 1995; 33: 335-343.

35. Fields H. Pain modulation: expectations, opioid analgesia and virtual pain. Prog Brain Res 2000; 122: 245-253.

36. Lee JE, Watson D, Frey Law LA. Lower-order pain-related constructs are more predictive of cold pressor pain ratings than higher-order personality traits. J Pain 2010; 11: 681-691.

37. Rifel J, Kersnik J. Problems of mental health at primary care level - how to recognise a depresive episode. Zdrav Vestn 2010; 79: 544-547.

38. Angst J, Gamma A, Gastpar M, Lepine JP, Mendlewicz J, Tylee A. Gender differences in depression: epidemiological findings from the European DEPRES I and II studies. Eur Arch Psychiatry Clin Neurosci 2001; 252: 201-209.

39. Selič P, Petek D, Pesjak K. Healthy, but are they satisfied? Factors associated with job satisfaction in professional soldiers of the Slovenian Armed Forces. J Def Manag 2012; 2: 103.

40. Zisook S, Schuter SR. Depression through the first year after the death of a spouse. Am J Psychiatry 1991; 148: 1346-1352.

41. Stansfeld S, Candy B. Psychosocial work environment and mental health-a meta-analytic review. Scand J Work Environ Health 2006; 32: 443-462.

42. Dolenc $P$, Pišot $R$, Šimunič $B$. Anxiety level and different stresscoping strategies of Slovenian soldiers. Zdrav Var 2009; 48: 114-121.

43. Griffin JM, Fuhrer R, Stansfeld SA, Marmot M. The importance of low control at work and home on depression and anxiety: do these effects vary by gender and social class? Soc Sci Med 2002; 54: 783-798.

44. Griffin JM, Greiner BA, Stansfeld SA, Marmot M. The effect of self-reported and observed job conditions on depression and anxiety symptoms: a comparison of theoretical models. J Occup Health Psychol 2007; 12: 334-349.

45. Williams PG, Wiebe DJ, Smith TW. Coping processes as mediators of the relationship between hardiness and health. $J$ Behav Med 1992; 15: 237-255.

46. Jex SM, Bliese PD, Buzzel S, Primeau J. The impact of self-efficacy on stressor-strain relations: Coping style as an explanatory mechanism. J Appl Psychol 2001; 86: 401-409.

47. Dirkzwager AJE, Bramsen I, Van Der Ploeg HM. Social support, coping, life events, and posttraumatic stress disorder symptoms among former peacekeepers: a prospective study. Pers Indiv Differ 2003; 34: 1545-1559.

48. Moos RH, Schaefer JA. Coping resources and processes: current concepts and measures. In: Goldberg L, Breznitz S, editors. Handbook of stress: theoretical and clinical aspects. Free Press, 1993: 234-257. 